\title{
Characteristics of Litchi Seed Germination
}

\author{
J.S. Prasad, Raj Kumar, Mukund Mishra, Rajesh Kumar, A.K. Singh, \\ and U.S. Prasad ${ }^{1}$ \\ Biosciences Research Centre, Botany Department, Tej Narain Banaili College, \\ Bhagalpur University, Bhagalpur-812 007, India
}

Additional index words. seed germination, litchi, gibberellic acid, indole-3-butyric acid, ethephon

\begin{abstract}
Seed germination of four Litchi chinensis Sonn. cultivars ('Deshi', 'Kasba', 'Purbi', and 'Early Bedana') was studied under various conditions, viz. in soil beds exposed to sunlight or in shade, in sand beds exposed to sunlight or in shade, and on moist filter paper. Among all, shaded, humid sand at $35 \pm 2 \mathrm{C}$ gave the highest germination. Delaying sowing seeds after removal from the fruit significantly reduced germination. Litchi seeds held in polyethylene bags up to 4 days at $37 \pm 2 \mathrm{C}$ at $90 \%$ relative humidity delayed loss of seed viability. Germination was improved by ethephon in 'Deshi' and 'Early Bedana', by IBA in 'Deshi' and 'Purbi', and by $100 \mathrm{~mm} \mathrm{GA}_{3}$ in all litchi cultivars. Cultivars responded differently to growth regulators, with 'Deshi' responding significantly better than 'Purbi', 'Kasba', or 'Early Bedana'. These studies point to the recalcitrant nature of litchi seeds. Chemical names used: gibberellic acid $\left(\mathrm{GA}_{3}\right)$; indole butyric acid (IBA); 2-chloroethylphosphonic acid (ethephon).
\end{abstract}

The heterogeneity of litchi propagated from seed may offer a method to develop new cultivars (Kadman and Slor, 1974; Kumar and Thakur, 1981). Litchi seed germination is sensitive to moisture (Fu et al., 1990; Ray and Sharma, 1985). However, the causes of rapid loss of seed viability by litchi and other recalcitrant seeds and the difficulties with longterm storage have not been investigated thoroughly (Chin, 1978; Chin et al., 1984; Fu et al., 1990; Kumari-Singh and Prasad, 1991). We investigated the germination of four cultivars of L. chinensis ('Deshi', 'Kasba', 'Purbi', and 'Early Bedana' ) under various conditions at $35 \pm 2 \mathrm{C}$ and $\approx 60 \% \mathrm{RH}$. How germination capacity was affected by physical (holding seed in polyethylene bags or in open containers at $37 \mathrm{C}$ and $\approx 90 \% \mathrm{RH}$ ) and chemical (effects of ethephon, IBA, or $\mathrm{GA}_{3}$ treatments was also studied.

\section{Materials and Methods}

Fruit samples. Fully ripe fruits $(\approx 2000)$ of 'Deshi', 'Kasba', 'Purbi', and 'Early Bedana' litchi were harvested from trees in the College of Agriculture, Sabour(Bhagalpur), India. Seed from the four cultivars was immediately sown in soil (loam) beds exposed to sunlight or

Received for publication 12 May 1995. Accepted for publication 4 May 1996. We thank the Principal, T.N.B. College, Bhagalpur, India, for necessary laboratory facilities, and the CSIR, India, for financial assistance to Mukund Mishra and Rajesh Kumar. The cost of publishing this paper was defrayed in part by the payment of page charges. Under postal regulations, this paper therefore must be hereby marked advertisement solely to indicate this fact. 'To whom reprint requests should be addressed. under shade, in sand beds exposed to sunlight or under shade, and on moist filter paper at ambient conditions $(35 \pm 2 \mathrm{C})$. Additional fresh seeds were used to test several treatments before sowing: 1) seeds were held in a $40-\mu \mathrm{m}$ thick polyethylene bag sealed with a rubber band, or were held in an open container, both at room temperature in a humidity-controlled chamber $(35 \pm 2 \mathrm{C}$ and $\approx 60 \% \pm 4 \% \mathrm{RH}$ as determined with a psychrometer); 2) seeds were sown 2,4,6, or $8 \mathrm{~h}$ after removal (HAR) from the fruit, in sand beds under shade; 3 ) seeds were held at $37 \mathrm{C}$ and $\approx 90 \% \pm 4 \% \mathrm{RH}$, either in an open container or in a polyethylene bag for $1,2,3$, or 4 days after removal (DAR) from the fruit and then sown in sand beds in shade.

Seeds were placed $2-3 \mathrm{~cm}$ deep in soil or sand. For each treatment there were four replications with 25 seeds per replication of each sowing condition and cultivar.

Seeds of each cultivar were soaked in 1,10 , or $100 \mathrm{~mm}$ of IBA, $\mathrm{GA}_{3}$, or ethephon for $1 \mathrm{~h}$ and then sown in a sand bed under shade. The

control was soaked in distilled water for $1 \mathrm{~h}$.

The beds were thoroughly irrigated in the morning and the evening. Germination was determined daily, with radicle emergence being the criterion of seed germination. Seeds that had not germinated after 8 days were subjected to amiability assay with $1 \%$ triphenyl tetrazolium chloride (TTC) solution. Data were subjected to three-factor randomized block design analysis of variance (ANOVA) with the help of Indostat Statistical Package according to Snedecor and Cochran(1961).

\section{Results and Discussion}

Germination conditions. Germination of litchi seed cultivars differed significantly and ranged from $92 \%$ in 'Deshi' to $60 \%$ in 'Early Bedana' sown in the sand bed under shade at 35C (Table 1 ). When the soil bed was exposed to sunlight, germination never exceeded $16 \%$. While there was a marked improvement in germination of seeds on moist filter paper, seeds failed to germinate in the sand bed exposed to sunlight and shaded soil bed under any of these conditions. Optimum germination occurred in seeds sown immediately after removal from the fruit. There was already a substantial decline in the germination percentage of all cultivars $2 \mathrm{~h}$ after removal from the fruit (Fig. 1). Seed held in a polyethylene bag mostly had a slower loss of germination ability than those held in an open container. 'Deshi' litchi seed held in bags lost germinability minimally during storage, irrespective of storage method; in contrast, 'Early Bedana' had lost its capacity to germinate within $8 \mathrm{~h}$ after removal from the fruit.

Seeds of all litchi cultivars, whether held in a polyethylene bag or not at $37 \mathrm{C}$ and $90 \% \mathrm{RH}$, lost germinability to various degrees (Fig. 2). Loss in 'Early Bedana' was the fastest. There was a rapid decline in germination with the increase in days after removal, with the decline being mostly less for seeds held in polyethylene bags (Table 2). Ray and Sharma (1985) reported greater retention of viability in seeds stored in water rather than in air. Ray and Sharma (1987) also reported $42 \%$ viability up to 24 days when seeds had been left in the fruit that was held in polyethylene bags following treatment with $0.05 \%$ methyl 1,2 benzimidazole carbamate (benomyl) and 6\%

Table 1. Percent germination of litchi seed under three conditions.

\begin{tabular}{lccc}
\hline \hline & \multicolumn{3}{c}{ Germination (\%) } \\
\cline { 2 - 4 } Cultivars & $\begin{array}{c}\text { Sand bed } \\
\text { under shade }\end{array}$ & $\begin{array}{c}\text { Soil bed } \\
\text { exposed to sunlight }\end{array}$ & $\begin{array}{c}\text { On moist filter paper } \\
\text { under ambient conditions }\end{array}$ \\
\hline Deshi & 92 & 0 & 23 \\
Kasba & 85 & 16 & 50 \\
Purbi & 84 & 16 & 40 \\
Early Bedana & 60 & 0 & 16 \\
& & Analysis of variance & Frobability \\
Source of variation & df & MS & 0.001 \\
Condition & 2 & 16152.25 & 0.0001 \\
Cultivar & 3 & 1055.52 & 0.001 \\
Condition $\times$ cultivar & 6 & 222.44 & \\
Error & 24 & 0.88875 &
\end{tabular}

${ }^{2}$ Seed germination was absent in the soil bed under shade and sand bed exposed to sunlight. 
wax emulsion. Cull and Paxton (1982) were able to retain viability for 1 or 2 weeks when stored in the fruit or in moist peatmoss in a freezer. Litchi seeds in intact fruit remain viable for 4 weeks (Menzel, 1985), losing viability within a day after separation from the fruit. However, adequate soil moisture and aeration were among principal requirements for optimum litchi seed germination (Xia et al., 1992a, 1992b). In our study, none of the seed of any cultivar germinated in a soil bed under shade (favoring retention of moisture, but less aeration) or in a sand bed exposed to sunlight (favoring more aeration but rapid loss of moisture), reaffirming Xia et al. ( 1992a). Further, germination of litchi seeds was high in a sand bed under shade with regular morning and evening irrigation. This high rate may be due to the better bed aeration and the shading, which reduced water loss from the bed.

Growth regulators. Soaking litchi seeds for $1 \mathrm{~h}$ in ethephon improved germinability of 'Deshi' at $10 \mathrm{~mm}$ and for 'Early Bedana' at 1 and $100 \mathrm{~mm}$ (Table 3). Reduced germinability

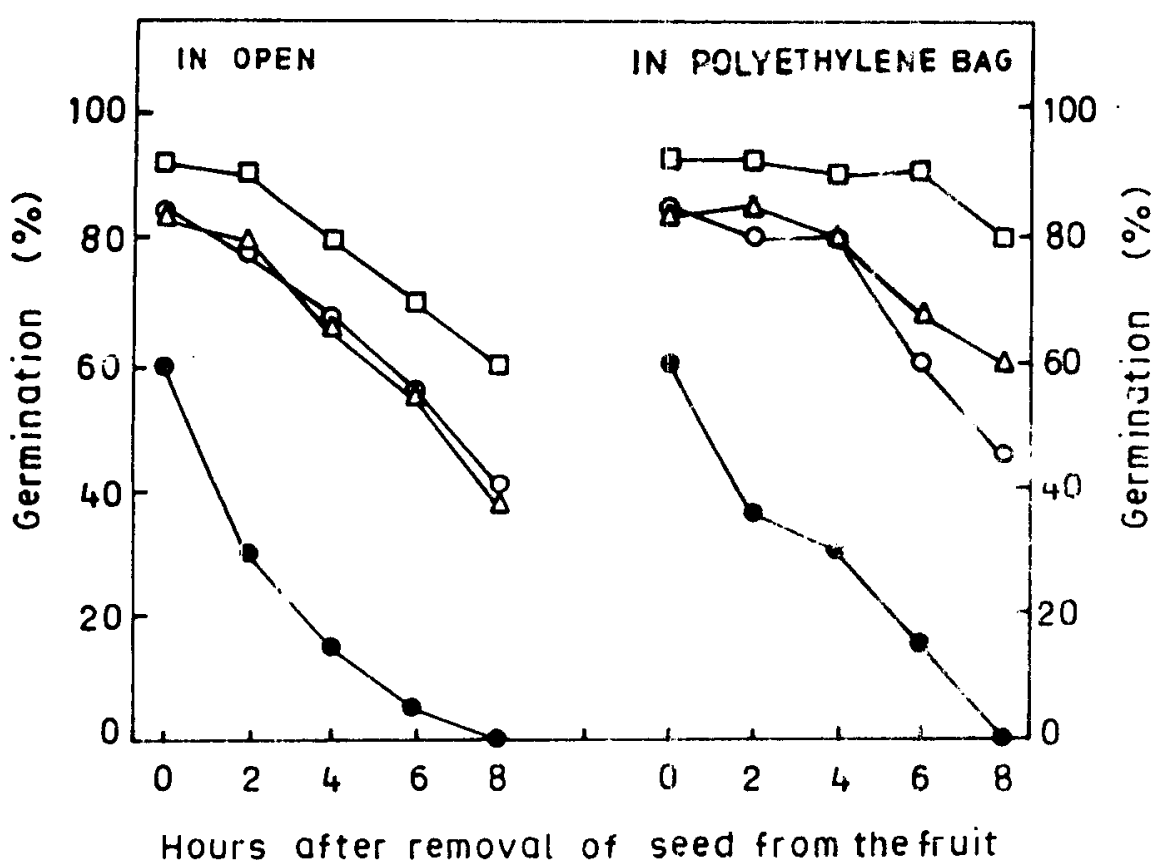

Fig. 1. Germination of litchi seeds held up to $8 \mathrm{~h}$ at 35C, 60\% RH ( $\square=$ 'Deshi'; $\mathrm{O}=$ 'Kasba'; $\Delta=$ 'Purbi'; - = 'Early Bedana').

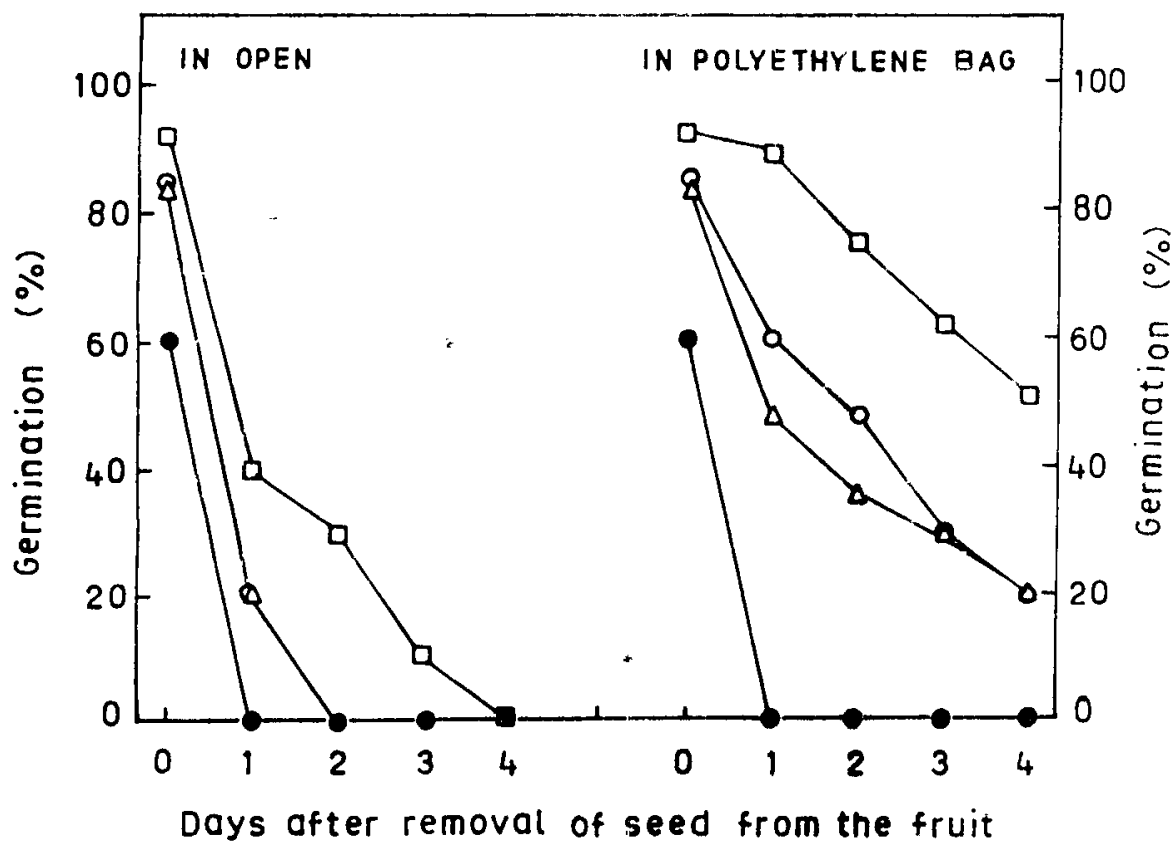

Fig. 2. Germination of litchi seeds held up to 4 days at 37C, 90\% RH ( $\square=$ 'Deshi'; $\mathrm{O}=$ 'Kasba': $\Delta=$ 'Purbi': $=$ 'Early Bedana'). with 10 mm may be due to chance. However, 1,10 , or 100 mm ethephon reduced germination in 'Kasba' and in 'Purbi'. The improving effect of IBA on 'Deshi' seed was similar to that of ethephon. In 'Purbi', 10 or $100 \mathrm{~mm}$ IBA improved germination. In 'Kasba' and 'Early Bedana', 1 and 10 mm IBA reduced germination. $\mathrm{GA}_{3}$ at $1 \mathrm{~mm}$ reduced germination in 'Deshi', 'Kasba', 'Purbi', and 'Early Bedana'. $\mathrm{GA}_{3}$ at $10 \mathrm{~mm}$ slightly improved germination in three cultivars, the exception being 'Kasba'. $\mathrm{GA}_{3}$ at $100 \mathrm{~mm}$ increased the germination of all cultivars (Table 3), suggesting that $\mathrm{GA}_{3}$ plays an important role in litchi germination. Sharma and Dhillon ( 1986) noted a decline in endogenous levels of gibberellin in litchi seeds at maturity. Such a decline may be a limiting factor in maintenance of seed viability and/or germination. Their results agree with those of Xia et al. (1992a) of a similar response to $\mathrm{GA}_{3}$ by longan (Euphoria longan Steud.) seeds. The effect of the three growth regulators on litchi seeds differed among cultivars.

Thus, litchi seed germination can be best achieved on a humid sand bed under shade immediately after removal of the seed from the fruit. With an increase in time after removal, germination capacity is lost, reflecting the recalcitrant nature of litchi seed. Its germinability can be improved by ethephon, IBA, and $\mathrm{GA}_{3}$ applications, among which $\mathrm{GA}_{3}$ plays a greater role than the other two growth regulators.

\section{Literature Cited}

Chin, H.F. 1978. Production and storage of recalcitrant seeds in the tropics. Acta Hort. 83:17-21.

Chin, H.F., Y.L. Hor, and M.B.M. Lassim. 1984. Identification of recalcitrant seeds. Seed Sci. \& Technol. 12:429-436.

Cull, B.W. and B.F. Paxton. 1982. Litchi (Litchi chinensis). Yearbook Western Austral. Nut Tree Crop Assn. 7:13-21.

Fu, J.R., B.Z. Zhang, X.P. Wang, Y.Z. Qiao, and X.L. Huang. 1990. Physiological studies on desiccation, wet storage and cryopreservation of recalcitrant seeds of three fruit species and their excised embryonic axes. Seed Sci. \& Technol. 18:743-754.

Kadman, A. and E. Slor. 1974. Experiments with propagation of the litchi (Litchi chinensis) in Israel. Indian J. Hort 31:28-33.

Kumar, R. and S. Thakur. 1981. Evolving new litchi cultivars for Bihar (in Hindi). Adhunik Kisan Patrika 11:31-33.

Kumari-Singh, A. and U.S. Prasad. 1991. Dehydration pattern and viability loss in seed of two cultivars of litchi (Litchi chinensis Sonn.). Seed Res. 19:41-43.

Menzel, C.M. 1985. Propagation of lychee: A review. Scientia Hort. 25:31-48.

Ray, P.K. and S.B. Shanna. 1985. Viability of Litchi chinensis seeds when stored in air and in water. J. Agr. Sci. (Cambridge) 104:247-248.

Ray, P.K. and S.B. Sharma. 1987. Growth, maturity, germination and storage of litchi seeds. Scientia Hort. 33:213-221.

Sharma, S.B. and B.S. Dhillon. 1986. Endogenous level of gibberellins in relation to fruit cracking in litchi (Litchi chinensis Sonn.). J. Res. Punjab Agr. Univ. 23:432-434.

Snedecor, G.W. and W.G. Cochran. 1961. Statistical methods. Allied Pacific Private Limited. Bombay. p. 359-360.

Xia, Q.H., R.Z. Chen, and J.R. Fu. 1992a. Effect of 
Table 2. Statistical analysis of germination data (ANOVA) presented in Figs. 1 and 2. Seeds A) were held up to $8 \mathrm{~h}$ at room temperature (35C, $60 \% \mathrm{RH})$ and $\mathrm{B})$ were held up to 4 days at $37 \mathrm{C}, 90 \% \mathrm{RH}$.

\begin{tabular}{lccc}
\hline Source of variation & df & MS & F probability \\
\hline & A) Hours after removal of seed from the fruit & \\
Replication & 1 & 0.62 & 0.599 \\
Hours (H) & 4 & 3932.30 & 0.000 \\
Storage method (SM) & 1 & 1280.00 & 0.002 \\
Cultivars (C) & 3 & 12826.80 & 0.000 \\
H $\times$ SM & 4 & 132.75 & 0.005 \\
H $\times$ C & 12 & 202.80 & 0.002 \\
SM $\times$ C & 3 & 47.33 & 0.002 \\
H $\times$ SM $\times$ C & 12 & 31.25 & 0.025 \\
Error & 39 & 2.22 & \\
& 1 & 1 & \\
Replication & 4 & 12267.25 & 0.269 \\
Days $(D)$ & 1 & 5933.40 & 0.000 \\
Storage method (SM) & 3 & 674.45 & 0.000 \\
Cultivars (C) & 4 & 223.48 & 0.000 \\
D $\times$ SM & 12 & 1363.06 & 0.001 \\
D $\times$ C & 3 & 119.48 & 0.025 \\
SM $\times$ C & 12 & 1.20 & 0.001 \\
D $\times$ SM $\times$ C & 39 & & 0.025 \\
Error & & & \\
\hline
\end{tabular}

Table 3. Effect of soaking in ethephon, IBA, and $\mathrm{GA}_{3}$ (in $\mathrm{mM}$ ) for $1 \mathrm{~h}$ on percent germination of four litchi cultivars.

\begin{tabular}{|c|c|c|c|c|c|c|c|c|c|c|}
\hline \multirow[b]{4}{*}{ Cultivars } & \multicolumn{10}{|c|}{ Germination (\%) } \\
\hline & \multirow[b]{3}{*}{ Control } & \multicolumn{7}{|c|}{ Growth regulators (mM) } & & \\
\hline & & \multicolumn{3}{|c|}{ Ethephon } & \multicolumn{3}{|c|}{ IBA } & \multicolumn{3}{|c|}{$\mathrm{GA}_{3}$} \\
\hline & & 1 & 10 & 100 & 1 & 10 & 100 & 1 & 10 & 100 \\
\hline$\overline{\text { Deshi }}$ & 92 & 94 & 100 & 94 & 93 & 100 & 94 & 87 & 94 & 100 \\
\hline Kasba & 85 & 73 & 47 & 47 & 54 & 67 & 80 & 73 & 73 & 94 \\
\hline Purbi & 84 & 80 & 73 & 80 & 80 & 94 & 94 & 80 & 87 & 94 \\
\hline Early Bedanna & 60 & 70 & 50 & 80 & 40 & 50 & 60 & 80 & 70 & 90 \\
\hline \multicolumn{11}{|c|}{ Analysis of variance } \\
\hline \multicolumn{2}{|l|}{ Replication } & \multicolumn{3}{|c|}{1} & & \multicolumn{2}{|c|}{4.16} & \multicolumn{3}{|c|}{0.105} \\
\hline \multicolumn{2}{|c|}{ Chemical (Chem) } & \multicolumn{3}{|c|}{2} & & \multicolumn{2}{|c|}{661.16} & \multicolumn{3}{|c|}{0.002} \\
\hline \multicolumn{2}{|c|}{ Concentration (Con) } & \multicolumn{3}{|c|}{3} & & \multicolumn{2}{|c|}{413.81} & \multicolumn{3}{|c|}{0.002} \\
\hline \multicolumn{2}{|c|}{ Cultivar $(\mathrm{C})$} & \multicolumn{3}{|c|}{3} & & \multicolumn{2}{|c|}{4282,15} & \multicolumn{3}{|c|}{0.000} \\
\hline \multicolumn{2}{|l|}{ Chem $\times$ Con } & \multicolumn{3}{|c|}{6} & & \multicolumn{2}{|c|}{314.11} & \multicolumn{3}{|c|}{0.001} \\
\hline \multicolumn{2}{|l|}{ Chem $\times \mathrm{C}$} & \multicolumn{3}{|c|}{6} & & \multicolumn{2}{|c|}{400.44} & & & 0.001 \\
\hline Con $\times \mathrm{C}$ & & & 9 & & & 26 & & & & 0.005 \\
\hline Chem $\times$ Con & & & 18 & & & & & & & 0.005 \\
\hline Error & & & 47 & & & & & & & \\
\hline
\end{tabular}

desiccation, temperature and other factors on the germination of lychee (Litchi chinensis Sonn.) and longan (Euphoria longan Steud.) seeds. Seed Sci. \& Technol. 20: 119-127.
Xia, Q.H., R.Z. Chen, and J.R. Fu. 1992b. Moist storage of lychee (Litchi chinensis Sonn.) and longan (Euphoria longan Steud.) seeds. Seed Sci. \& Technol. 20:269-279. 